\title{
Modifikasi sistem kultur in vitro untuk meningkatkan vigor planlet stevia (Stevia rebaudiana Bert.)
}

\author{
Modification of in vitro culture system to increase the vigor of stevia (Stevia rebaudiana Bert.) plantlets
}

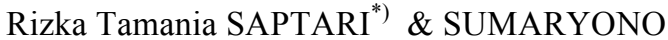

Pusat Penelitian Bioteknologi dan Bioindustri Indonesia, J1. Taman Kencana No.1, Bogor 16128, Indonesia

Diterima tanggal 1 Maret 2016 /disetujui tanggal 10 November 2016

\begin{abstract}
Stevia (Stevia rebaudiana Bert.), a sweetener plant, has been mass propagated by tissue culture technique. Optimal conditions to increase vigor of stevia plantlets are needed to support the sustainability of in vitro plantlet stocks and increase plantlet survival rate during acclimatization. The aim of this research was to investigate the effect of different media, culture vessel sizes, and vessel closure types on the vigor of stevia plantlets. The plant material was derived from apical shoot cuttings of sterile stevia plantlets grown on WP medium without growth regulator. Several treatments used in this study were solid or double layer media; short or tall culture vessel; and polypropile screw cap or plastic film closures. Growth of plantlets was determined after 3 weeks of culture. Temperature and light intensity inside the vessels were also observed. The results showed that the best treatment to increase the vigor of stevia plantlets was a double-layer medium in a tall culture vessel (diameter $7 \mathrm{~cm}$ and height $11 \mathrm{~cm}$ ) with either screw cap or plastic film. It was exhibited by significantly bigger stem diameter, more and bigger leaves, longer roots, and higher biomass fresh weight than those of other treatments. Higher temperature was observed on tall culture vessel, whereas all treatments did not significantly affect light intensity inside the vessels.
\end{abstract}

[Keywords: stevia, plantlet vigor, double-layer medium, culture vessel size, vessel closure]

\section{Abstrak}

Stevia (Stevia rebaudiana Bert.), tanaman pemanis, telah diperbanyak melalui teknologi kultur jaringan. Kondisi kultur optimal untuk meningkatkan vigor planlet stevia masih diperlukan untuk mendukung keberlanjutan tanaman stock in vitro dan untuk meningkatkan daya hidup planlet ketika diaklimatisasi. Penelitian yang dilakukan bertujuan untuk menentukan pengaruh penggunaan jenis media, ukuran botol kultur, dan jenis penutup botol yang berbeda terhadap vigor planlet stevia. Material tanaman yang digunakan didapat dari potongan tunas apikal plantlet stevia steril yang

\footnotetext{
*) Penulis korespondensi: rizkatamania@iribb.org
}

ditumbuhkan pada media WP tanpa zat pengatur tumbuh. Perlakuan jenis media terdiri atas media padat dan media dua-lapis (double-layer), ukuran botol pendek dan tinggi, serta jenis tutup ulir berbahan polipropilen dan lembaran plastik transparan. Pengamatan pertumbuhan planlet dilakukan setelah 3 minggu, juga dilakukan pengamatan terhadap suhu dan intensitas cahaya di dalam botol kultur. Hasil penelitian memperlihatkan bahwa perlakuan terbaik untuk meningkatkan vigor planlet stevia adalah dengan menggunakan media dua-lapis dalam botol kultur (diameter $7 \mathrm{~cm}$, dan tinggi $11 \mathrm{~cm}$ ), baik dengan tutup ulir maupun plastik. Hal ini ditunjukkan dari diameter batang lebih besar, daun lebih banyak dan besar, akar lebih panjang, serta bobot segar biomassa lebih tinggi dibandingkan dengan perlakuan lainnya. Suhu lebih tinggi terukur pada perlakuan botol tinggi, sedangkan semua perlakuan tidak mempengaruhi secara nyata intensitas cahaya di dalam botol kultur.

[Kata kunci: stevia, vigor, media dua-lapis, ukuran botol kultur, tutup botol]

\section{Pendahuluan}

Stevia rebaudiana Bert. (famili Asteraceae) merupakan tanaman perdu tahunan yang berasal dari Paraguay. Stevia termasuk tanaman hari pendek, tumbuh optimal pada daerah subtropis dengan suhu rata-rata $23^{\circ} \mathrm{C}$ dan curah hujan 1.500-1.800 mm/tahun (Pande \& Priyanka, 2013), namun sekarang telah menyebar luas termasuk di wilayah tropis. Saat ini, Cina menjadi negara produsen dan penyalur stevia terbesar di dunia, sedangkan Jepang sebagai target market utama (Das et al., 2015; Ijaz et al., 2015).

Stevia merupakan salah satu tanaman penghasil glikosida steviol, yaitu senyawa sekunder yang memiliki rasa manis, namun tanpa kalori. Terdapat 11 jenis glikosida steviol yang terkandung dalam stevia, paling utama adalah steviosida dan rebaudiosida A (Das et al., 2006; Kroyer, 2010; Pande \& Priyanka, 2013).

Glikosida tersebut terutama terdapat pada daun dengan kandungan 4-15\% dari berat kering daun dan dengan tingkat kemanisan 200-300 kali dibandingkan sukrosa (Mogra \& Dashora, 2009). Stevia telah digunakan sebagai pemanis alami yang bersifat non-karsinogenik dan bebas kalori karena glikosidanya tidak mengalami metabolis- 
me di dalam tubuh manusia. Konsumsi stevia sangat baik bagi penyandang diabetes dan obesitas (Mogra \& Dashora, 2009).

Selain metode konvensional, perbanyakan stevia dapat dilakukan dengan kultur in vitro menggunakan eksplan buku, ruas, dan daun (Anbazhagan et al., 2010; Verma et al., 2011). Pertumbuhan tanaman in vitro ditentukan oleh komposisi media dan kondisi lingkungan mikro di dalam botol kultur. Pertumbuhan tanaman yang baik salah satunya dicirikan dengan planlet yang vigor atau kokoh. Vigor planlet menentukan keberlanjutan hidup planlet pada saat disubkultur atau diaklimatisasi.

Ketersediaan planlet in vitro yang mencukupi sangat diperlukan dalam produksi benih stevia skala besar. Subkultur planlet dilakukan untuk menjaga ketersediaan planlet. Oleh karena itu, diperlukan planlet dengan vigor tinggi agar mampu terus beregenerasi selama dilakukan subkultur. Peningkatan vigor planlet dapat dilakukan dengan modifikasi komposisi media seperti hara, hormon, vitamin, dan senyawa penunjang, maupun lingkungan mikro seperti suhu, intensitas cahaya, dan pertukaran gas. Sebagai contoh, penambahan paklobutrazol 0,1 $\mathrm{mg} / \mathrm{L}$ pada media MS di bawah lampu fluoresen dengan intensitas cahaya $20 \mu \mathrm{mol} / \mathrm{m}^{2} /$ detik mampu meningkatkan vigor planlet stevia (Sumaryono \& Sinta, 2011).

Media sebagai sumber hara diperlukan untuk pertumbuhan planlet. Jenis media dan kepadatannya menentukan pertumbuhan tanaman in vitro. Media padat berfungsi sebagai penopang planlet yang memiliki risiko kontaminasi rendah, namun daya serap hara oleh sel tanaman terbatas. Sebaliknya, media cair memungkinkan sel tanaman untuk menyerap hara lebih banyak dan cepat (Jones et al., 2007), namun seringkali meningkatkan risiko kontaminasi dan hyperhidricity pada tanaman (Tacsan et al., 2010; Dewir et al., 2014). Penggunaan media dua-lapis (double layer) yaitu penambahan media cair di atas media padat mampu memadukan kelebihan media padat dan media cair. Media dua-lapis telah banyak digunakan untuk optimasi pertumbuhan berbagai tanaman in vitro (de Oliveira, 2011; Scherwinski-Pereira et al., 2012; de Oliveira et al., 2013; Gatambia et al., 2016).

Selain jenis media, pemilihan botol kultur, dan jenis penutup yang digunakan juga dapat mempengaruhi pertumbuhan tanaman in vitro (Huang \& Chen, 2005). Botol kultur dan penutupnya mempengaruhi kondisi lingkungan mikro di dalam botol kultur, seperti laju pertukaran gas, distribusi dan intensitas cahaya, serta suhu. Botol kultur yang baik mampu mencegah masuknya kontaminasi dan hilangnya air, namun memungkinkan masuknya cahaya dan sirkulasi gas yang baik (Chen, 2003). Penutup botol yang berbeda berpengaruh terhadap tingkat kontaminasi planlet microcutting karet (Nurhaimi-Haris et al., 2009), dan daya hidup serta pertumbuhan planlet kelapa sawit (Sinta et al., 2011). Penelitian ini bertujuan untuk mengetahui pengaruh jenis media, ukuran botol, dan jenis tutup botol terhadap vigor planlet stevia.

\section{Bahan dan Metode}

\section{Bahan tanam dan kondisi kultur}

Penelitian dilakukan di Laboratorium Biak Sel \& Mikropropagasi Tanaman, Pusat Penelitian Bioteknologi dan Bioindustri Indonesia, Bogor. Bahan yang digunakan adalah tunas pucuk satu ruas yang berasal dari kultur in vitro stevia klon Biotek-X. Kultur in vitro stevia berumur lima tahun dan menggunakan media Woody Plant (WP).

\section{Perlakuan dan pengamatan}

Perlakuan pada penelitian ini yaitu dua jenis media (padat atau dua lapis), ukuran botol (tinggi atau pendek), dan jenis tutup botol (tutup ulir atau tutup plastik). Jenis media yang digunakan yaitu media WP yang ditambahkan $30 \mathrm{~g} / \mathrm{L}$ sukrosa. Media padat adalah media WP yang ditambahkan $3 \mathrm{~g} / \mathrm{L}$ gelrite sebagai bahan pemadat. Sedangkan media dua lapis adalah media padat yang di atasnya ditambahkan $5 \mathrm{~mL}$ media cair per botol. Tingkat $\mathrm{pH}$ media diatur menjadi 5,7 sebelum media disterilisasi menggunakan autoklaf pada suhu $121{ }^{\circ} \mathrm{C}$ dan tekanan $1 \mathrm{~kg} / \mathrm{cm}^{2}$. Botol pendek berukuran diameter $6 \mathrm{~cm}$, tinggi $9 \mathrm{~cm}$, dan volume $250 \mathrm{~mL}$. Sedangkan botol tinggi berukuran diameter $7 \mathrm{~cm}$, tinggi $11 \mathrm{~cm}$, dan volume $350 \mathrm{~mL}$. Tutup ulir berbahan polipropilen, sedangkan tutup plastik adalah selembar plastik transparan yang tahan diautoklaf. Sebagai kontrol adalah media padat dalam botol pendek menggunakan tutup ulir.

Sebanyak 8 botol kultur masing-masing berisi 5 tunas pucuk stevia digunakan sebagai ulangan untuk setiap perlakuan. Kultur diinkubasi pada ruang dengan suhu $25 \pm 1{ }^{\circ} \mathrm{C}$, fotoperiode 12 jam per hari, di bawah sebuah lampu TL $36 \mathrm{~W}$ selama 3 minggu tanpa subkultur.

Parameter penelitian yang diamati setelah 3 minggu meliputi tinggi planlet, jumlah ruas, jumlah daun, luas daun (panjang x lebar), panjang akar, diameter batang, dan bobot segar biomassa planlet. Planlet dikeluarkan dari botol kultur, kemudian dibersihkan dari media agar yang menempel. Diameter batang diukur pada $1 \mathrm{~cm} \mathrm{di}$ atas pangkal batang menggunakan jangka sorong.

Suhu di dalam botol kultur diukur dengan termometer digital Fluke $51 \mathrm{~K} / \mathrm{J}$. Ujung sensor termometer ditempatkan dalam botol kultur berisi media. Pengamatan suhu dilakukan setiap interval 1 jam selama sebelas jam selama periode terang, dan dilakukan selama 2 hari sebagai pengulangan waktu. Pengukuran intensitas cahaya di dalam botol kultur menggunakan lightmeter LI-COR 250 dengan sensor quantum meter yang diletakkan dalam botol sesuai dengan perlakuan. Botol kultur ditempatkan di bawah 1 buah 
lampu TL $36 \mathrm{~W}$ dengan suhu ruangan $25^{\circ} \mathrm{C}$. Pengukuran intensitas cahaya dilakukan pada 6 titik lokasi cahaya sebagai ulangan (Gambar 1). Pengukuran intensitas cahaya hanya dilakukan pada perlakuan ukuran botol dan jenis tutup botol karena intensitas cahaya pada perlakuan jenis media dianggap sama.

\section{Rancangan percobaan dan analisis statistik}

Penelitian menggunakan Rancangan Acak Lengkap (RAL) dengan 3 faktorial yaitu kepadatan media (padat; dua-lapis), ukuran botol (pendek; tinggi), dan jenis penutup botol (tutup ulir; plastik). Setiap perlakuan diulang sebanyak 8 kali (botol kultur berisi 5 planlet). Data dianalisis menggunakan analisis sidik ragam yang dilanjutkan dengan uji Jarak Berganda Duncan (DMRT) pada taraf kepercayaan $\alpha \leq 0,05$. Analisis juga dilakukan terhadap masing-masing faktor perlakuan untuk melihat perlakuan yang berpengaruh terhadap vigor planlet stevia.

\section{Hasil dan Pembahasan}

\section{Vigor planlet stevia}

Ukuran botol, jenis tutup botol, dan jenis media yang berbeda mempengaruhi pertumbuhan dan vigor planlet stevia pada 3 minggu setelah kultur (Tabel 1). Planlet yang ditanam pada media padat dalam botol tinggi menggunakan tutup plastik memiliki ukuran tertinggi, dan berbeda nyata dengan planlet yang ditanam pada media padat dalam botol pendek dengan tutup ulir (kontrol). Planlet yang pendek juga dihasilkan pada perlakuan media padat dalam botol pendek. Tinggi planlet stevia pada umur 3 minggu telah mencapai $9,5 \mathrm{~cm}-11,1 \mathrm{~cm}$ yang melebihi tinggi botol kultur sehingga batang planlet mulai melingkar (Gambar 2).

Jumlah ruas terbanyak dihasilkan dari perlakuan media dua-lapis dalam botol pendek dengan tutup ulir, berbeda nyata dengan perlakuan media padat dalam botol pendek dengan tutup plastik dan media padat dalam botol tinggi dengan tutup ulir. Jumlah daun terbanyak dihasilkan pada perlakuan media dua-lapis dalam botol tinggi baik dengan tutup ulir maupun dengan tutup plastik yang mencapai 15 helai daun per planlet.

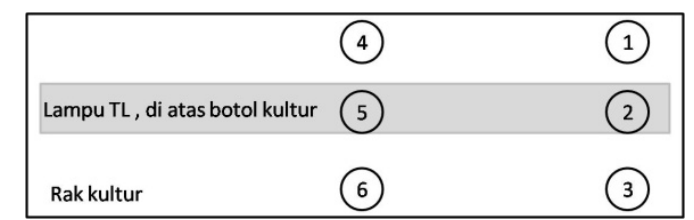

Gambar 1. Titik sampel pengukuran intensitas cahaya dalam botol kultur.

Figure 1. Sample point for the measurement of light intensities inside vessels.

Tabel 1. Pengaruh jenis media, ukuran botol, dan jenis tutup botol terhadap vigor planlet stevia setelah kultur 3 minggu.

Table 1. Effect of media, vessel size, and closure type on the vigor of stevia plantlets after 3 weeks of culture.

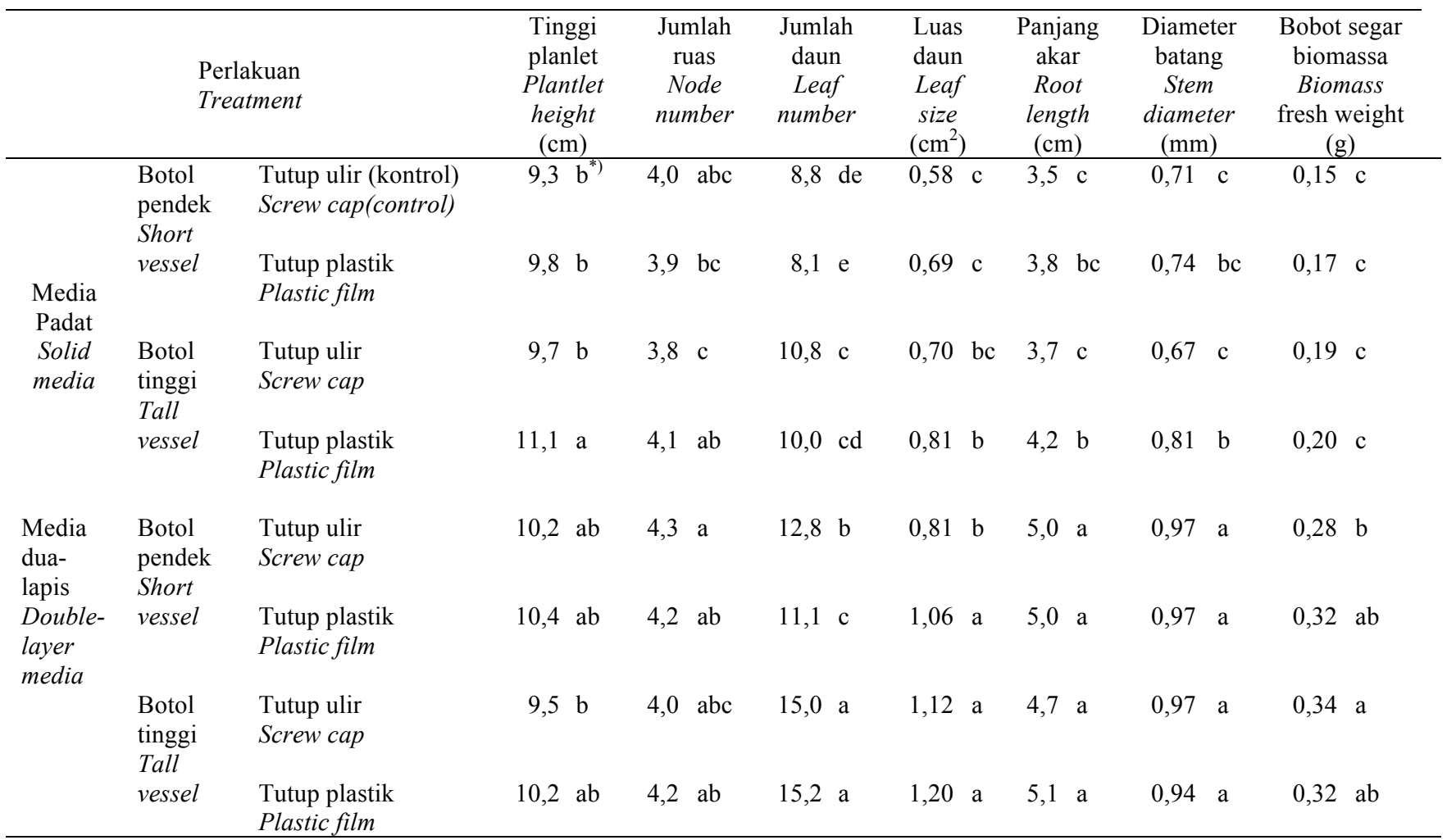

*) Huruf yang sama pada kolom yang sama menunjukkan angka yang tidak berbeda nyata menurut uji jarak berganda Duncan dengan $\alpha \leq 0,05$.

${ }^{*}$ Same letters in the same coloumn indicate that means are not significantly different according to Duncan's multiple range test at $\alpha \leq 0.05$. 
Luas daun terbesar dihasilkan pada perlakuan media dua-lapis dalam botol tinggi dengan tutup ulir atau tutup plastik, dan media dua-lapis dalam botol pendek dengan tutup plastik.

Diameter batang, bobot segar biomassa, dan panjang akar terbesar dihasilkan pada perlakuan media dua-lapis pada semua ukuran botol dan jenis tutup botol kultur. Berdasarkan hasil pada Tabel 1, vigor planlet stevia terbaik mengacu pada diameter batang, ukuran daun, dan bobot segar biomassa tertinggi, dihasilkan dari perlakuan media dua-lapis pada botol tinggi baik menggunakan tutup ulir maupun dengan tutup plastik.

Untuk mengetahui pengaruh faktor perlakuan terhadap vigor planlet stevia, dilakukan analisis statistik menurut faktor perlakuan tunggal, yaitu jenis media, ukuran botol, dan jenis tutup botol. Hasil analisis tersebut menunjukkan bahwa perlakuan jenis media mempengaruhi jumlah ruas, jumlah daun, luas daun, panjang akar, diameter batang, dan bobot segar biomassa planlet. Hasil menunjukkan planlet yang ditanam pada media dua-lapis lebih tinggi dibandingkan dengan media lain.Hal tersebut memperlihatkan bahwa media dua-lapis berpengaruh sangat baik terhadap pembentukan vigor planlet stevia. Media dua-lapis mempermudah penyerapan hara dari media oleh sel eksplan. Semakin banyak hara yang dapat terserap, semakin optimal pertumbuhan tanaman sehingga planlet lebih vigor. Hasil serupa dilaporkan oleh Gatambia et al. (2016) pada kultur in vitro pepaya dan oleh de Oleivera et al. (2013) pada kultur vanili menunjukkan bahwa penggunaan media dua-lapis dapat meningkatkan perakaran, jumlah daun, laju multiplikasi, dan ukuran tunas. Media dua-lapis banyak digunakan pada teknik kultur jaringan untuk menginduksi perakaran. Selain menghasilkan perakaran yang baik, penggunaan media dua-lapis juga mampu meningkatkan pertumbuhan tunas, seperti memperbanyak jumlah tunas dan meningkatkan vigor tunas.

Perlakuan ukuran botol mempengaruhi tinggi planlet, jumlah daun, luas daun, dan bobot segar biomassa planlet. Planlet yang ditanam dalam botol tinggi menunjukkan hasil yang lebih baik dibandingkan dengan ukuran botol lainnya. Botol tinggi memiliki volume lebih besar dibandingkan dengan botol pendek. Menurut Kozai (2010), penggunaan botol kultur dengan volume besar lebih membantu menciptakan kondisi lingkungan mikro yang diinginkan planlet dibandingkan dengan botol kultur yang memiliki volume lebih kecil. McClelland \& Smith (1990) melaporkan bahwa pertumbuhan tunas dari lima spesies tanaman berkayu lebih optimal pada penggunaan botol kultur yang lebih besar.

Subkultur planlet stevia biasa dilakukan dengan interval tiga minggu. Setelah tiga minggu, pertambahan tinggi planlet akan/melebihi tinggi botol sehingga arah pertumbuhan planlet saling mendesak satu sama lain terutama pada penggunaan botol pendek. Hal tersebut dapat menghambat pertumbuhan, terutama tinggi planlet. Pertumbuhan planlet dapat mendesak tutup botol, menyebabkan adanya kompetisi hara, dan makin tingginya akumulasi gas-gas penghambat pertumbuhan akibat sempitnya volume botol kultur. Penggunaan botol kultur yang tinggi memungkinkan pertumbuhan planlet yang tetap tegak dan tidak saling mendesak (Gambar 2). Pada umur tiga minggu, planlet dalam botol tinggi, tingginya belum mencapai puncak botol, sehingga waktu subkultur dapat ditunda menjadi empat minggu. Penundaan waktu subkultur dapat meningkatkan efisiensi waktu dan tenaga kultur di laboratorium.

Perlakuan tutup botol mempengaruhi tinggi planlet, luas daun, dan panjang akar yang lebih tinggi pada penggunaan tutup plastik dibanding tutup ulir. Namun, pada perlakuan terbaik yakni media dua-lapis dalam botol tinggi, kedua jenis tutup botol yakni tutup plastik dan tutup ulir tidak berpengaruh terhadap vigor planlet stevia dalam hal jumlah daun, luas daun, panjang akar, diameter batang, dan bobot segar biomassa (Tabel 2). Pemilihan botol kultur beserta penutupnya memberikan pengaruh yang besar dalam menciptakan iklim mikro yang sesuai untuk pertumbuhan tanaman. Sebagai contoh, perlakuan jenis tutup botol dapat mempengaruhi penyerapan cahaya serta kelembaban dalam botol kultur (Huang \& Chen, 2005; Kartsonas \& Papafotiou, 2010). Penggunaan tutup plastik transparan menyerap cahaya lebih banyak dibandingkan dengan tutup ulir yang dapat meningkatkan pertumbuhan planlet stevia. Namun pada penggunaan media dua-lapis, nutrisi tersedia lebih mudah diserap sehingga mampu menunjang pertumbuhan planlet baik pada kondisi cahaya di dalam botol yang optimal maupun kurang.

\section{Suhu di dalam botol kultur}

Hasil penelitian menunjukkan bahwa pada saat periode gelap, suhu di dalam botol kultur pada seluruh perlakuan tidak berbeda nyata dengan suhu di luar botol (Tabel 2). Pada saat periode gelap, lampu flouresen tidak menyala sehingga tidak menghasilkan sumber panas yang menyebabkan perbedaan suhu antara di luar dan di dalam botol kultur.

Suhu di dalam botol untuk seluruh perlakuan saat periode terang berbeda nyata dengan suhu di luar botol. Suhu di dalam botol lebih tinggi berkisar antara $0,9^{\circ} \mathrm{C}$ sampai $1,3^{\circ} \mathrm{C}$ (Tabel 2). Pada periode tersebut, lampu fluoresen memancarkan cahaya dan panas yang diterima oleh kultur in vitro melewati dinding-dinding botol dan tutup botol yang mampu ditembus cahaya sehingga suhu dalam botol meningkat (Huang \& Chen, 2005). Suhu dalam botol menjadi lebih tinggi pada perlakuan media dualapis dalam botol tinggi dengan tutup ulir, dan media dua-lapis dalam botol pendek dengan tutup plastik. Hasil ini berbeda nyata hanya dengan 


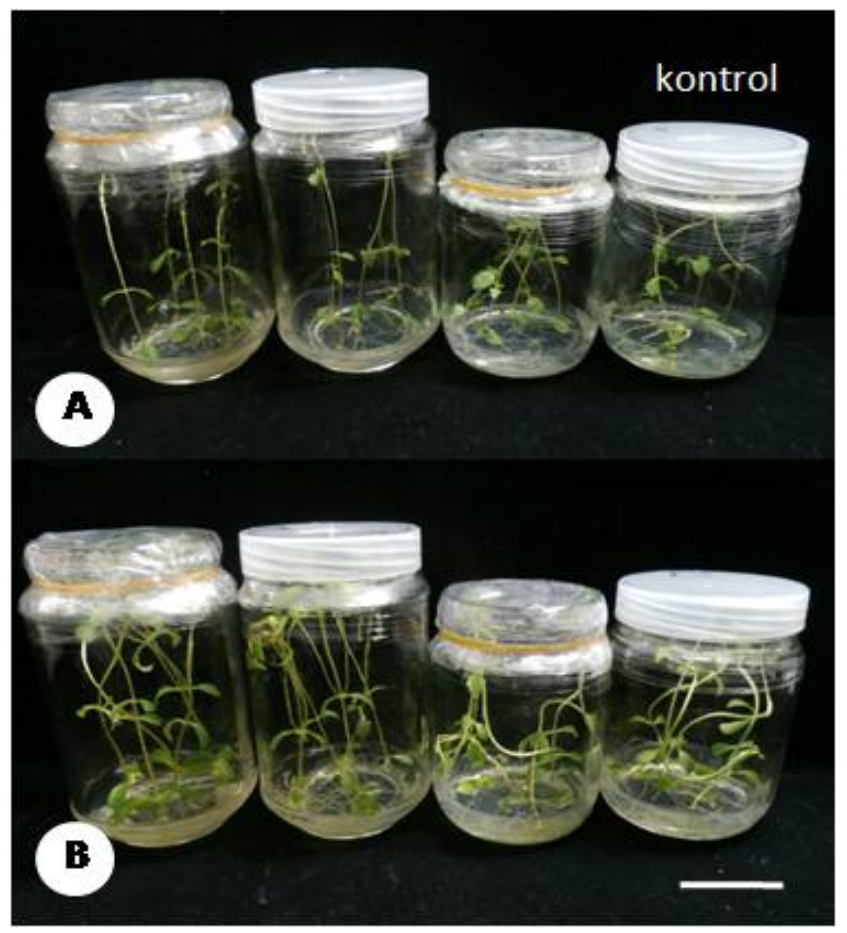

Gambar 2. Pengaruh jenis media, ukuran botol, dan jenis tutup botol terhadap vigor planlet stevia setelah kultur 3 minggu: $\mathrm{A}=$ Media padat (berurutan dari kiri ke kanan) : botol tinggi-tutup plastik, botol tinggi-tutup ulir, botol pendek-tutup plastik, botol pendek-tutup ulir (kontrol); B = Media dua-lapis: botol tinggi-tutup plastik, botol tinggi-tutup ulir, botol pendek-tutup plastik, botol pendek-tutup ulir. Bar $=3 \mathrm{~cm}$.

Figure 2. Effect of of media, vessel size, and closure type on the vigor of stevia plantlets after 3 weeks of culture: $A=$ Solid media (from left to right): tall bottle-plastic film, tall bottle-screw cap, short bottle-plastic film, short bottle-screw cap (control); $B=$ Double layer media: tall bottle-plastic film, tall bottle-screw cap, short bottle-plastic film, short bottle-screw cap. Bar $=3 \mathrm{~cm}$.

perlakuan kontrol (Tabel 2).

Hasil analisis statistik terhadap masing-masing faktor perlakuan menunjukkan bahwa hanya ukuran botol yang mempengaruhi suhu dalam botol kultur. Suhu dalam botol pendek lebih rendah berbeda nyata dengan suhu dalam botol tinggi. Botol tinggi memiliki volume yang lebih besar yaitu $350 \mathrm{~mL}$, dibandingkan dengan botol pendek yaitu $250 \mathrm{~mL}$. Menurut Islam et al. (2005), volume botol yang lebih besar memungkinkan terjadinya sirkulasi gas lebih baik sehingga suhu dalam botol relatif tidak terpengaruh. Sirkulasi gas di dalam botol kultur menentukan suhu dalam botol kultur. Secara umum sistem kultur in vitro adalah tertutup dan hampir kedap udara.

Hasil percobaan memperlihatkan bahwa botol tinggi memiliki suhu dalam botol yang lebih tinggi dibandingkan dengan botol pendek. Hal ini dikarenakan panas yang diterima oleh botol kultur tinggi lebih banyak dibandingkan dengan botol kultur pendek karena memiliki permukaan botol yang lebih besar sehingga luas bidang penangkapan cahaya dan panas lebih besar (Chen, 2003). Jenis media, baik padat maupun dua-lapis tidak mempengaruhi suhu dalam botol kultur.

Suhu dalam lingkungan mikro kultur in vitro mampu mempengaruhi pertumbuhan planlet berkaitan dengan enzim-enzim yang berperan dalam metabolisme tanaman (Lin et al., 2006).
Enzim memiliki suhu optimal tertentu untuk mampu bekerja secara optimal. Salah satu enzim yang terlibat dalam proses fiksasi $\mathrm{CO}_{2}$ dalam reaksi gelap fotosintesis yaitu enzim fosfoenolpiruvat karboksilase diketahui aktivitasnya meningkat sejalan dengan peningkatan suhu lingkungan (Lin et al., 2006).

\section{Intensitas cahaya di dalam botol kultur}

Ukuran botol dan jenis tutup botol tidak mempengaruhi intensitas cahaya dalam botol kultur berdasarkan hasil analisis statistik. Intensitas cahaya di dalam botol lebih rendah secara nyata dibandingkan dengan intensitas cahaya di luar botol (Tabel 3). Ketika cahaya mengenai dinding botol, sebagian cahaya diteruskan ke dalam botol, dan sebagian lainnya dipantulkan kembali sehingga jumlah berkas cahaya dalam botol lebih rendah dibandingkan dengan cahaya luar. Selisih berkas cahaya dalam botol dengan cahaya luar yaitu sekitar 0,82-1,09 $\mu \mathrm{mol}$ foton $/ \mathrm{m}^{2} /$ detik. Penelitian yang dilaporkan oleh Sinta et al. (2011) pada planlet kelapa sawit dengan penggunaan tutup botol yang berbeda menunjukkan adanya selisih intensitas cahaya antara di luar dan di dalam botol sebesar 1,7-8,7 $\mu \mathrm{mol}$ foton $/ \mathrm{m}^{2} /$ detik. Semakin kecil selisih antara intensitas cahaya di luar dan di dalam botol, maka semakin banyak jumlah foton yang tersedia di 
Tabel 2. Suhu di dalam botol kultur dengan jenis media, ukuran botol, dan jenis tutup botol yang berbeda.

Table 2. Temperature inside culture vessels with different media, vessel sizes, and closure types.

\begin{tabular}{|c|c|c|c|c|}
\hline & $\begin{array}{l}\text { Perlakuan } \\
\text { Treatment }\end{array}$ & & $\begin{array}{c}\text { Suhu periode gelap } \\
\text { Dark period temperature } \\
\left({ }^{\circ} \mathrm{C}\right)\end{array}$ & $\begin{array}{c}\text { Suhu periode terang } \\
\text { Light period temperature } \\
\left({ }^{\circ} \mathrm{C}\right)\end{array}$ \\
\hline \multirow[t]{4}{*}{$\begin{array}{l}\text { Media padat } \\
\text { Solid media }\end{array}$} & $\begin{array}{l}\text { Botol pendek } \\
\text { Short vessel }\end{array}$ & $\begin{array}{l}\text { Tutup ulir (kontrol) } \\
\text { Screw cap (control) }\end{array}$ & $\left.24,6 \mathrm{a}^{*}\right)$ & $25,7 \quad b$ \\
\hline & & $\begin{array}{l}\text { Tutup plastik } \\
\text { Plastic film }\end{array}$ & 24,6 a & $26,0 \mathrm{ab}$ \\
\hline & $\begin{array}{l}\text { Botol tinggi } \\
\text { Tall vessel }\end{array}$ & $\begin{array}{l}\text { Tutup ulir } \\
\text { Screw cap }\end{array}$ & 24,6 a & 26,1 a \\
\hline & & $\begin{array}{l}\text { Tutup plastik } \\
\text { Plastic film }\end{array}$ & 24,6 a & 26,1 a \\
\hline \multirow{4}{*}{$\begin{array}{l}\text { Media dua-lapis } \\
\text { Double-layer } \\
\text { media }\end{array}$} & $\begin{array}{l}\text { Botol pendek } \\
\text { Short vessel }\end{array}$ & $\begin{array}{l}\text { Tutup ulir } \\
\text { Screw cap }\end{array}$ & 24,5 a & $25,9 a b$ \\
\hline & & $\begin{array}{l}\text { Tutup plastik } \\
\text { Plastic film }\end{array}$ & 24,5 a & $26,1 \quad a$ \\
\hline & $\begin{array}{l}\text { Botol tinggi } \\
\text { Tall vessel }\end{array}$ & $\begin{array}{l}\text { Tutup ulir } \\
\text { Screw cap }\end{array}$ & 24,5 a & 26,0 ab \\
\hline & & $\begin{array}{l}\text { Tutup plastik } \\
\text { Plastic film }\end{array}$ & 24,4 a & $26,0 \quad a b$ \\
\hline \multicolumn{2}{|c|}{$\begin{array}{l}\text { Suhu di luar botol }\left({ }^{\circ} \mathrm{C}\right) \\
\text { Outside temperature }\left({ }^{\circ} \mathrm{C}\right)\end{array}$} & & 24,2 a & 24,8 a \\
\hline
\end{tabular}

Tabel 3. Intensitas cahaya dalam botol kultur dengan ukuran botol dan jenis tutup botol berbeda.

Table 3. Light intensity inside culture vessel with different vessel sizes and closure types.

\begin{tabular}{llc}
\hline & $\begin{array}{l}\text { Perlakuan } \\
\text { Treatment }\end{array}$ & $\begin{array}{c}\text { Intensitas cahaya }\left(\mu \mathrm{mol} / \mathrm{m}^{2} / \mathrm{detik}\right) \\
\text { Light intensity }\left(\mu \mathrm{mol} / \mathrm{m}^{2} / \mathrm{s}\right)\end{array}$ \\
\hline $\begin{array}{l}\text { Botol pendek } \\
\text { Short vessel }\end{array}$ & $\begin{array}{l}\text { Tutup ulir (kontrol) } \\
\text { Screw cap (control) } \\
\text { Tutup plastik } \\
\text { Plastic film }\end{array}$ & $\left.6,85 \mathrm{a}^{*}\right)$ \\
\hline Botol tinggi & Tutup ulir \\
Tall vessel & Screw cap & $6,92 \mathrm{a}$ \\
& $\begin{array}{l}\text { Tutup plastik } \\
\text { Plastic film }\end{array}$ & $6,65 \mathrm{a}$ \\
\hline & $6,88 \mathrm{a}$ \\
Intensitas cahaya di luar botol & $7,74 \mathrm{a}$ \\
Light intensity outside vessels
\end{tabular}

${ }^{*}$ Nilai rata-rata tidak berbeda nyata menurut uji jarak berganda Duncan dengan $\alpha \leq 0,05$.

${ }^{*}$ Means are not significantly different according to Duncan's multiple range test at $\alpha \leq 0,05$.

dalam botol kultur. Hal tersebut akan meningkatkan suhu di dalam botol, seperti yang dilaporkan oleh Chen (2003) bahwa penyinaran mempengaruhi suhu kultur in vitro. Tanaman membutuhkan foton dari penyinaran sebagai sumber energi untuk menjalankan fotosintesis.
Menurut Ma et al. (2015), intensitas cahaya juga mempengaruhi aktivitas enzim-enzim fotosintesis di dalam xantofil. Sumaryono \& Sinta (2011) melaporkan bahwa intensitas cahaya terbaik untuk pembentukan vigor planlet stevia yaitu sebesar $20 \mu \mathrm{mol}$ foton $/ \mathrm{m}^{2} /$ detik dengan menggunakan dua buah lampu TL $36 \mathrm{~W}$. 
Penelitian menggunakan satu buah lampu TL $36 \mathrm{~W}$ sehingga intensitas cahaya di dalam botol kurang dari $10 \mu \mathrm{mol}$ foton $/ \mathrm{m}^{2} /$ detik. Intensitas cahaya sebesar 11-75 $\mu \mathrm{mol}$ foton $/ \mathrm{m}^{2} /$ detik mampu meningkatkan laju fotosintesis dengan meningkatkan efisiensi pigmen fotosintesis untuk menangkap foton (Bartual et al., 2002). Oleh karena itu, hasil penelitian menunjukkan terjadinya perbedaan vigor planlet stevia tidak dipengaruhi oleh intensitas cahaya. Intensitas cahaya pada setiap perlakuan tidak berbeda dan sangat rendah yaitu kurang dari $10 \mu \mathrm{mol}$ foton $/ \mathrm{m}^{2} /$ detik (Tabel 3).

\section{Kesimpulan}

Vigor planlet stevia terbaik diperoleh pada media dua-lapis (media padat dilapisi media cair) dalam botol kultur tinggi (tinggi $11 \mathrm{~cm}$, diameter $7 \mathrm{~cm}$, dan volume $350 \mathrm{~mL}$ ) dengan diameter batang lebih besar, daun lebih banyak dan besar, akar lebih panjang, serta bobot segar biomassa lebih tinggi.

\section{Daftar Pustaka}

Anbazhagan M, M Kalpana, R Rajendran, V Natarajan \& D Dhanavel (2010). In vitro production of Stevia rebaudiana Bertoni. Emir J Food Agric 22(3), 216-222.

Bartual A, LM Lubian \& JA Galvez (2002). Effect of irradiance on growth, photosynthesis, pigment content and nutrient consumption in dense cultures of Rhodomonas salina (Wislouch) (Cryptophyceae). Ciencas Marinas 28(4), 381-392.

Chen C (2003). Development of heat transfer model for plant tissue culture vessels. Biosys Engin 85 (1), 67-77.

Das A, D Paul, AK Golder \& C Das (2015). Separation of rebaudioside-A from stevia extract: Membrane selection, assessment of permeate quality and fouling behaviour in laminar flow regime. Separ Purif Tech 144, 815.

Das K, R Dang \& PE Rajasekharan (2006). Establishment and maintenance of callus of Stevia rebaudiana Bertoni under aseptic environment. Nat Prod Radiance 5(5), 373376.

de Oliveira F (2011). Micropropagation of Pinus taeda L. via axillary buds. BMC Proc 5, Suppl 7, 144 .

de Oliveira SOD, RM Sayd, TA Balzon \& JE Scherwinski-Pereira (2013). A new procedure for in vitro propagation of vanilla (Vanilla planifolia) using double-phase culture system. Sci Hort 161, 204-209.

Dewir YH, Y Indoliya, D Chakrabarty \& K Paek (2014). Biochemical and physiological aspects of hyperhydricity in liquid culture system. In: Production of Biomass and Bioactive Compounds Using Bioreactor Technology. Springer. p. 693-709.

Gatambia EK, AW Kihurani, FK Rimberia \& MM Waiganjo (2016). In vitro meristem culture for rapid regeneration of papaya plantlets in liquid media. Ann Res Rev Biol 9(1), 1-7.

Huang C \& C Chen (2005). Physical properties of culture vessel for plant tissue culture. Biosyst Engin 91(4), 501-511.

Ijaz M, AM Pirzada, M Saqib \& M Latif (2015). Stevia rebaudiana: An alternative sugar crop in Pakistan-a Review. J Med Spice Plant 20(2), 88-96.

Islam MT, DP Dembele \& ERJ Keller (2005). Influence of explant, temperature and different culture vessels on in vitro culture for germplasm maintenance of four mint accessions. Plant Cell Tiss Org Cult 81, 123130.

Jones MPA, Z Yi, SJ Murch \& PK Saxena (2007). Thidiazuron-induced regeneration on Echinacea purpurea L.: Micropropagation in solid and liquid culture systems. Plant Cell Rep 26, 13-19.

Kartsonas E \& M Papafotiou (2010). Effect of culture vessels size and covering materian on leaf morphological and anatomical characteristics of Quercus euboica in vitro plantlets. Acta Hort. (ISHS) 885, 191-196

Kozai T (2010). Photoautotrophic micropropagation-environmental control for promoting photosynthesis. Prop Ornam Plants 10, 188-204.

Kroyer G (2010). Stevioside and stevia-sweetener in food: Application, stability and interaction with food ingredients. $J$ Verbr Lebensm 5, 225-229.

Lin Q, S Abe, A Nose, A Sunami \& Y Kawamitsu (2006). Effects of high night temperature on crassulacean acid metabolism (CAM) photosynthesis of Kalanchoe pinnata and Ananas comosus. Plant Prod Sci 9, 10-19.

Ma P, T Bai, X Wang \& F Ma (2015). Effect of light intensity on photosynthesis and photoprotective mechanisms in apple under progressive drought. J Integr Agric 14(9), 1755-1766.

McClelland MT \& MAL Smith (1990). Vessel type, closure, and explant orientation influence in vitro performance of five woody species. Hort Sci 25(7), 797-800.

Mogra R \& V Dashora (2009). Exploring the use of Stevia rebaudiana as a sweetener in 
comparison with other sweeteners. J Hum Ecol 25, 117-120.

Nurhaimi-Haris, Sumaryono \& MP Carron (2009). Pengaruh bahan pra-sterilan, tutup tabung kultur, dan musim terhadap tingkat kontaminasi eksplan pada kultur microcutting karet. Menara Perkebunan 77(2), 84-93.

Pande SS \& G Priyanka (2013). Plant tissue culture of Stevia rebaudiana (Bertoni). J Pharmacognosy \& Phytotherapy 5(1), 26-33.

Scherwinski-Pereira, JE, ECA Lima, TL da Silva, AGG Mesquita, SA Maciel\& FHS Costa (2012). Double-phase culture system for large scale production of pineapple. Plant Cell Tiss Org Cult 109, 263-269.

Sinta MM, I Riyadi \& Sumaryono (2011). Pengaruh jenis penutup botol kultur terhadap pertumbuhan planlet kelapa sawit (Elaeis guineensis Jacq.). Menara Perkebunan 79(1), $15-22$.

Sumaryono \& MM Sinta (2011). Peningkatan laju multiplikasi tunas dan keragaan planlet Stevia rebaudiana pada kulturin vitro. Menara Perkebunan 79(2), 49-56.

Tacsan A, J Adelberg, M Tacsan, ARimando, N Joshee \& AK Yadav (2010). Hyperhydricity and flavonoid content of Scutellaria species in vitro on polyester-supported liquid culture systems. Hort Sci 45(11), 1723-1728.

Verma S, K Yadav \& N Singh (2011). Optimization of the protocols for surface sterilization, regeneration and acclimatization of Stevia rebaudiana Bertoni. AmericanEurasian J AgricEnviron Sci 11(2), 221-227. 